\title{
Pasiruošimas Kalèdų šventėms vilniečių šeimose: stresas ar malonumas?
}

\author{
RASA PAUKŠTYTE்-ŠAKNIENE் \\ Lietuvos istorijos institutas, Kražiu g. 5, LT-01108 Vilnius \\ El. paštas: rasa.sakniene@gmail.com
}

\begin{abstract}
Dovanų dovanojimas neabejotinai svarbus socialinis reiškinys, kuris neretai yra neatsiejama ritualo dalis, formuojanti priklausomybès šeimai ir platesnèms socialinėms bendrijoms jausmus. Dovanos yra ypač svarbi Kalèdų šventės dalis. Jų paieška kartais ženkliai pratęsia pasiruošimo šventei laiką ir gali sukelti stresą. Pasiremdama Jono Helslooto pasiūlyta ritualo atlikimo teorine prieiga ir skatinimu patikrinti ritualinio streso apraiškas kitose šalyse mėginsiu tai paanalizuoti šiame straipsnyje. Darbas paremtas 2012-2013 m. etnografiniu lauko tyrimu Vilniaus mieste.
\end{abstract}

Raktažodžiai: stresas, Vilnius, Kalèdų dovanos, Kūčios, šeima

Christopho Wulfo teigimu, Kalèdų šventės gali būti suvokiamos skirtingai: vaiko, laukiančio atvykstančio Santa Klauso, tèvų, kuriems malonu suteikti vaikui džiaugsmą, paauglio sūnaus, manančio, kad Kalèdos tuščia ir nuobodi šventè, ir senelès, prisimenančios Kalèdų šventimą jaunysteje. Ritualas padeda ịveikti šiuos skirtumus ir atnaujinti priklausomybės šeimai ir bendruomenei jausmus bei tapatumą [24, 399-400].

Libertas Klimka pažymi, kad XX a. pradžioje iš esmès kintant visuomenès struktūrai, pamažu neliko tos terpès, kurioje susiformavo tradicinè kultūra [7, 131]. Šiame straipsnyje pažvelgsime ị XXI a. vilniečių šventinę kultūrą taip, kaip ji kuriama, pasak Tomo Hylando Erikseno, „greitèjančio laiko epochoje“, kuris, anot etnologo, susijęs su precizijos praradimu ir dabarties iššǔkiais nesiderinančiame šeiminiame gyvenime [3]. Prieš kelerius metus J. Helslootas publikavo straipsni „Stresas ir ritualas. Gruodžio mènesio šeimos tradicijos šių dienų Nyderlanduose“, kuriame, remdamasis ritualo atlikimo (angl. performance) šalininkų Edwardo Schieffelino, Cliffordo Geertzo ir Ronaldo Grimeso suformuota rizikingo, galinčio nepavykti ir stresą sukeliančio ritualo teorine prieiga, analizavo Nyderlandų gruodžio mėnesio šventes (Šv. Mikalojaus (1) ir Kalėdų), jas siedamas su stresu, patiriamu joms ruošiantis ir jose dalyvaujant. Autorius sieke atkreipti dẻmesị $\mathfrak{x}$ streso reiškinị bei žmonių nurodytus jo požymius [6, 143-158]. Pasiremdama

(1) Didesnèje Europos dalyje gruodžio 6-ąją švenčiant Šv. Mikalojaus dieną ịprasta teikti dovanas [20, 85]. Marija Znamierowska-Prüfferowa prisimena, kad Vilniaus mieste „dèl kai kurių Lenkijos regionų ịtakos nešamos dovanos vaikams, tą dieną slepiamos ịvairiose kertėse“ [32, 140-141]. XX a. antrojoje pusejje su šv. Mikalojumi dovanų dalijimas buvo susijęs ir Punsko apylinkėse, tačiau šv. Mikalojus dovanas atnešdavo per Kūčias [15, 189]. 
olandų mokslininko skatinimu patikrinti ritualinio streso apraiškas kitose šalyse šiame straipsnyje paanalizuosiu vilniečių ruošimąsi gruodžio mẻnesio šventėms - Kalèdoms ir iš dalies Naujiesiems metams.

Šiuo metu Lietuvoje Kaledos yra viena svarbiausių kalendorinių švenčių, kuriai skirtos trys nedarbo dienos. Nuo 1990-ųjų Kalèdas šventėme dvi dienas, o 2012 m. Lietuvos Respublikos Seimas nedarbo diena patvirtino ir Kūčias. Tai tampa svaria priežastimi paanalizuoti kultūrinius ir socialinius ritualinių metų aspektus, ypatingą dèmesị atkreipiant ¡̇ šią šventę.

Daugelyje etnografinių aprašų šventẻ ir ją sudarantys ritualai sutrikdo įprastą gyvenimo ritmą. Pasak Jono Balio, šventès - tai malonios prošvaistės monotoniškame kaimo gyvenime $[2,5]$. Daugelio krikščioniškų tautų tradicinejje kultūroje iš metų švenčių išsiskiria Kalèdos. Lietuvoje ypatinga reikšmė teikiama ir šios šventès išvakarèms - Kūčioms. Vienu ar kitu aspektu šias šventes tyrinėjo daugelis Lietuvos etnologų. Bene išsamiausiai jas išanalizavo Juozas Kudirka, pasitelkęs etnografinę medžiagą, daugiausia sukauptą iš kaimiškų Lietuvos vietovių. Autorius, remdamasis lyginamosios kalbotyros ir vienos kultūrinès istorinès etnologijos mokyklos tyrimo metodų teikiamomis galimybėmis, siekẻ rekonstruoti senąją lietuvių kultūrą $[9,17]$. Pasak jo, Kalèdų išvakarès skiriasi giliu religiniu susikaupimu, pasiruošimu Kristaus gimimo šventei, ir liaudies pasaulejautoje Kūčios tapo neatskiriama Kalèdų šventès dalimi [9, 3; plg. 30, 135].

Tačiau ruošiantis šventei reikia ir tam tikrų pastangų. J. Kudirkos teigimu, net ir per Kūčias „nuo ankstyvo ryto visi dirba, dideli ir maži, vyrai ir moterys“ [8, 34]. Nemažai duomenų, kaip Lietuvos vietovėse seniau ir dabar švenčiamos Kalèdų šventès, galima rasti vietiniuose leidiniuose (2), tačiau apie šventimą miestiečių šeimose žinoma nedaug. Antrojo pasaulinio karo metų Vilnių aprašiusios etnologės M. Znamierowskos-Prüfferowos knygoje Vilnius, miestas arčiausia širdies pasiruošimas Kūčioms apibūdinamas taip:

„Anksčiau baigèsi darbas, pavėlavusieji dar bėga paskutinių eglučių. Judejjimas gatvėse ir krautuvèse gerokai didesnis. Visi skuba, kad suspètų, kad pasiruoštų tai vakaro valandai, ir vis dèlto virš visa to tvyro kažkoks susikaupimas ir iškilmingumas...Kaipgi karšta virtuvejje, kai reikia pagaminti tiek valgių, o kambarị papuošti ir padengti stalą..." $[32,141-142]$.

Etnologe pripažįsta, kad didesnis pasiruošimo šventei krūvis tekdavo moteriai. Daugiau panašaus pobūdžio miesto tyrimų neturime. Nèra tyrinèta ir kaip pastaraisiais metais šiai šventei ruošiamasi kitose Lietuvos vietovèse.

Iš kaimyninių šalių norèčiau išskirti Lenkijoje 2010 m. atliktą Bożenos Gierek Kalèdų šventès tyrimą. Šioje šalyje, kaip ir Lietuvoje, šventei teikiama išskirtinė reikšmė. Autorè, daugiausia apklaususi 20-30 metų amžiaus pateikejjus, priejo išvadą, kad 16 proc. lenkų Kalėdos asocijuojasi su pasiruošimu šventei, ị kurị ịtraukiami visi šeimos nariai - tai pirkimas parduotuvėse ir namų švarinimas, o 15 proc. pateikèjų šventes sieja su stresu, apsipirkimo karštlige, eilemis, transporto kamščiais mieste. Tyrimas taip pat atskleide, kad pasiruošimas šventei, ypač valgio gaminimas, daugiausia gula ant moters pečių [4, 236; 238]. Wendy Welch teiginys, kad moterys vis dažniau yra šventės kūrèjos, organizatorès ir administratorès [31, 179], paskatino paanalizuoti, kaip šventei ruošiamasi vilniečių šeimoje, daugiau dèmesio sutelkti į moterų patirtis.

Nekyla abejonių, kad ši šventė daugelyje šeimų švenčiama iki šių dienų. Kalèdų negalètume atsieti nuo religinio šios šventès konteksto. Milda Ališauskienè ir Ina Samuilova,

(2) Šios medžiagos, tiesiogiai nesusijusios su miesto kultūra, plačiau neaptarsime. 
atlikusios religijos tyrimą (3), kuriuo siekta nustatyti modernizacijos reikšmę individų religijai sovietinèje ir posovietinèje Lietuvoje, teigia, kad religinès vertybès ir ịgūdžiai buvo perduodami iš kartos ị kartą ir šiam procesui politinès sistemos kaita didesnès ịtakos neturèjo $[1,70]$.

Sociologè Jolanta Kuznecovienė, analizavusi kokios šventès ir kodèl lietuviams svarbiausios, teigè, kad „nors interviu duomenys (2005 m.) parode், kad visiems informantams svarbiausia šventė yra Kalèdos, tačiau dauguma informantų neatsieja šv. Kalèdų nuo Kūčių ir daugumai Kūčių vakaras yra svarbesnis bei ypatingesnis" [10,77].

Mano tyrimas, paremtas 2011 metų etnografinio lauko tyrimo duomenimis, analizuojant šiuolaikinio jaunimo švenčiamas kalendorines bei gyvenimo ciklo šventes Vilniaus mieste, taip pat rodo, kad Kūčias ir Kalèdas jaunimas išskiria kaip labiausiai tradicinę, iš senelių, tèvų perimtą, ir įvardija kaip pačią svarbiausią ir mėgstamiausią kalendorinę ir šeimos šventę. Prioritetas teikiamas todèl, kad šios šventès labiausiai sutelkia šeimą. Tyrimas taip pat atskleidè, kad daliai vilniečių labiau patinka ruoštis šventèms nei jas švęsti. Jiems pasiruošimas šventei yra malonus, nes šiame procese dalyvauja visi ar bent dauguma šeimos narių (4).

Pasiruošimas šventèms apima pirkimą bei šventinių dovanų pakavimą; maisto produktų pirkimą; namų tvarkymą bei puošimą, šventinio valgio gaminimą bei stalo dengimą; taip pat Kaledinių sveikimų ruošimą ir siuntimą bei daugelị kitų darbų. Visa tai susiję su kasmet išgyvenamu prieššventiniu rūpesčiu, kuris gali sukelti stresą. Šiame straipsnyje susitelksiu tik ị vieną pateikẻjų požiūriu ypač svarbų pasiruošimo šventei aspektą - jų veiksmus, susijusius su kalėdinių dovanų ruošimu / pirkimu, ir tik fragmentiškai paliesiu kitus pasiruošimo šventei momentus. Straipsnyje keliami uždaviniai: 1) pažvelgti ị dovanos reikšmę teoriniame ir praktiniame kontekste; 2) atskleisti pateikejų reikalavimus dovanai ir gebejjimą susidoroti su stresu, kylančiu ją ruošiant; 3) išsiaiškinti gaminamos ir perkamos dovanos ypatumus; 4) išanalizuoti pateikejų patirti planuojant prieššventinị laikotarpị, kuri padeda išvengti streso. Prieššventiniu dovanu ruošimo laikotarpiu vadinsime laiką nuo dovanų ruošimo / pirkimo pradžios, kuris gali prasidèti prieš 2-3 ménesius (ar net anksčiau), iki dovanos itteikimo per šventes. Naudojamas lyginamasis ir interpretacinis tyrimo metodai.

Straipsnis paremtas 2013 m. etnografinio lauko tyrimo Vilniaus mieste medžiaga. Pagal autorès sudarytą klausimyną "Gruodžio mẻnesio dovanos ir šventinis stalas“ tyrimo metu apklausta dvylika ịvairaus amžiaus (gimusių 1945-1982 m.) moterų. Pateikèjos klausinètos apie asmeninę patirtị, kuri susiklostè jų šeimose pasiruošimo šventėms laikotarpiu, pagrindinị dėmesị skiriant pasirengimui 2012 metų Kalėdų ir Naujụjų metų šventèms. Aiškintasi, ar praleistas laikas ruošiant dovanas pateikejjoms buvo malonus, ar sukèlè stresą. Užduodant šiuos ir kitus klausimus dėmesys buvo sukoncentruotas ne tik ị pateikèjų veiksmus, bet ir jų išsakytus išgyvenimus / būsenas prieššventiniu dovanų ruošimo laikotarpiu (5).

(3) $2010 \mathrm{~m}$. atliktas empirinis tyrimas, kurio metu apklausta 20 vidutinio ir vyresnio amžiaus informantų.

(4) Autorès straipsnis „Tradicija šiuolaikinių kalendorinių ir gyvenimo ciklo švenčių kontekste“ šiais metais itteiktas spaudai.

(5) Šio tyrimo metu dèmesys buvo sutelktas ị dovanas, kurias teikia ir gauna šeimos nariai. Atsiribojama nuo dovanų, kurias, pvz., vaikai gauna vaikų darželyje, mokykloje ar suaugusieji keisdamiesi darbo kolektyvuose. 
Pasiremsiu ir 2012 m. surinkta medžiaga (apklausiau 10 pateikejjų) apie vilniečių šventes pagal mano sudarytą klausimyną „Laisvalaikio ir šventinè kultūra šeimoje“ (6).

\section{DOVANOS REIKŠMĖ}

Marselis Mausas atkreipé dèmesị $\mathfrak{i}$ tai, kad dovanojimas niekada nèra vienpusis aktas - tai abipusių apsikeitimų - resiproksijos - principo igyvendinimas [14]. Arnoldo Van Gennepo teigimu, mainai tiesiogiai išreiškia tam tikrą suvaržymą - gaunantis dovaną įsipareigojimais susiejamas su jos daveju [27, 29]. Pasikeitimas dovanomis, pasak Arūno Vaicekausko, yra būdingas kiekvienam svarbesniam ritualui [25, 32-38]. Kalėdinès dovanos Lietuvoje, kaip ir daugelyje Europos kraštų, yra susijusios su eglutès puošimo papročiu.

Kaip atsirado paprotys per Kalèdas keistis dovanomis (XVI a. duomenys) arba puošti eglutę (pirmą kartą paminèta 1605 m. Štrasburge), nèra išaiškinta [5, 231]. XIX a. pirmojoje pusėje kalėdinès eglutės pradètos puošti ir Rusijos miestuose, kuriuose gyveno vokiečių $[13,20]$. Taigi tikètina, kad paprotys ị Lietuvą plito tiek per Mažąą Lietuvą, tiek ir iš Rusijos.

Kalėdinès dovanos Lietuvoje yra gana vėlyvas reiškinys, nors pirmas Kalėdų eglutės paminejjimas žinomas 1853 m. (poetas Antanas Baranauskas ją matė Vainute) [8, 53]. J. Kudirkos teigimu, XX a. pradžioje kartu su kalèdinèmis eglutėmis iš Vakarų Europos pradejo plisti vaikų apdovanojimo paprotys (7), tik po Pirmojo pasaulinio karo kai kur Lietuvoje dovanomis pradejo keistis ir suaugusieji $[8,215]$.

Dovanas, dažniausia maisto produktus, gaudavo ir Kalèdų antrąją dieną ar per visą tarpušventị sodybas lankantys jaunuoliai - persirengèliai $[8,224-242 ; 18,41-46$; 26, 94-197]. Maisto produktų (kai kur vadinta kūčia, kalèdina, kalėda) dažnai gaudavo ir iki Kalèdų tarnavę samdiniai. Kai kada vyrams samdiniams dar pridėdavo keletą litų, o merginoms - audeklo, skarelę, palaidinę, pirštines, batus, papuošalų [17, 55-57].

Anglijoje ịsigalejjusi kalèdinių dovanų tradicija XIX a. 5-6-uoju dešimtmečiais išstūmè suaugusiųu paproti dovanoti vieni kitiems dovanas per Naujuosius metus [31, 65] (8). Sovietų Sąjungoje XX a. viduryje paplitusios tradicijos - dovanoti vaikams per Naujuosius metus dovanas - negalètume ịvardyti nauju reiškiniu. Sovietmečiu perèjimo apeigų (rites de passage) simboliką ịkūnijusią Kalèdų šventę visuotinai buvo siekta perkelti ị Naujuosius metus, o per Naujuosius dovanas dalijantis Senis Šaltis daugeliui tapo neatsiejama šios šventès dalimi $[5,33]$. Pasak Dalios Senvaitytès, ypač daug dėmesio to meto ideologijoje ir spaudoje (1953-1964 m. duomenys) buvo skiriama naujametėms šventėms vaikams populiarinti: mokyklose, įmonių, kolūkių klubuose ir kitur. Akcentuojamas ne tik šventès linksmumas, bet ir dovanojamos dovanos, daug dèmesio buvo skirta eglučių puošimui. Tuo metu moksleivių atostogos prasidèdavo prieš Naujuosius metus ir jie neturèjo laisvų dienų per Kalèdas. Valdžios taikomos priemonès turèjo nukreipti žmonių dėmesi nuo krikščioniškų Kalèdų i pasaulietinius Naujuosius metus [22, 116-117], tačiau, kaip pažymi Jonas Mardosa, Kūčių šventẻ net ir šiuo laikotarpiu buvo plačiai švenčiama. Nors nemažai gyventojų daliai religinė Kalèdų prasmẻ buvo pakitusi, tačiau ši šventė laikyta

(6) Etnografinè lauko tyrimų medžiaga saugoma Lietuvos istorijos instituto Etnologijos skyriuje.

(7) Emanuilio Rikmano manymu, saldumynai, žaislai ir pinigai rodo dovanojimo desakralizaciją [33, 175].

(8) Šis procesas turèjo kelias priežastis: švenčiant šią šventę sureikšminami vaikai; iš Vokietijos atėjęs paprotys dèti dovanèles po Kalèdų eglute ir pigūs masinès gamybos žaislai, eksportuojami iš Vokietijos [23, 65]. 
tradicine šeimos švente ir kartu su tikinčiaisiais ją šventė ir netikintieji [11,65]. Angelès Vyšniauskaitès teigimu, naujosios sovietinès šventès pasižymėjo organizuotumu ir masiškumu [29, 561], tačiau vargu ar sovietinè ideologija galejo turèti didesnę reikšmę šeimose švenčiamoms šventėms. Pasak J. Mardosos, liaudies kultūroje nebuvo kanono. Žmonėms buvo priimtinas tas šventès pavidalas, kuris atitiko jų lūkesčius, vertybines ir pasaulèžiūrines nuostatas, o dirbtiniai apeiginių veiksmų diegimo variantai sunkiai ịsivaizduojami $[12,55]$.

Šių dienų mieste, kaip rodo pastarasis tyrimas, dažnas pateikejjas Naujųjų metų šventès nesureikšmina ir dažniausia šia proga dovanų nedovanoja. Retais atvejais šeimoje dovanos teikiamos tik vaikams, bet ir jos, 1963 m. gimusios pateikejos teigimu, perkamos kartu su kalėdinèmis. Ko gero, dovanų įsigalejjimui įtakos turèjo sovietmečiu Naujųjų metų proga teiktos dovanos vaikų darželiuose, mokyklose, vaikai gaudavo dovanų ir iš tėvų darboviečių (9). 1960 m. gimusi vilnietė pasakojo, kad kol vaikai buvo maži, dovanèles jiems pirkdavo ir nuo Kalèdų iki Naujųjų metų kas rytą po eglute dėdavo po dovanèlę. 1948 m. gimusi pateikejja taip pat pripažįsta, kad sovietmečiu ši šventẻ buvo labai sureikšminta. Jos nuomone, tuomet ne visi galèjo laisvai švęsti Kalèdas, tačiau dabar jos tapo pagrindine gruodžio mėnesio švente. Panašios nuostatos laikosi ir $1934 \mathrm{~m}$. gimęs vilnietis - jam pasiruošimas Kalèdoms visuomet buvęs svarbus, tačiau šito negalètų pasakyti apie Naujuosius metus. O 1976 m. gimusi pateikèja Naujųjų metų nešvenčia ne tik dabar, bet nešventė ir vaikysteje (nors augo sovietmečiu), todèl neturi dovanojimo tradicijos.

Jau minejjau, kad kalėdinių dovanų tradicija nėra senas reiškinys. 2013 m. apklaustų dviejų vyriausių pateikejų, gimusių pokario metais, pasakojimai skiriasi. 1948 m. gimusi ir užauginusi du vaikus dabar trijų anūkų močiutė apie dovanų pirkimo bei pasiruošimo šventèms patirti pasakojo su didžiuliu malonumu, nes jai Kūčios ir Kalėdos nuo vaikystės yra pati gražiausia metų šventė. Pateikejja yra pokario vaikas ir jos vaikystejje dovanų nebuvo, nors eglute būdavo. Tẻvų namuose dovanos pradètos dovanoti tik XX a. 7-ajji dešimtmetí, kai ji buvo paauglè. Pateikejos vaikai taip pat augo sovietmečiu, tačiau šeimoje kalèdinèms dovanoms buvo teikiamas ypatingas dèmesys: pagal išgales visada stengèsi nupirkti, kad ir smulkias, bet mielas, ypač vaikus pradžiuginančias dovanas. 1949 m. gimusi pateikèja, gyvenanti viena (netekejjusi), dabar dovanų nebeperka, o seniau pirko sūnènams, kol buvo maži. Nors iki dabar šventes dažniausia praleidžia su brolio šeima, paklausta, kodèl nebeperka dovanų, teigè, kad „tokia tradicija ateina nuo tėvų“. Pateikejja iš tėvų dovanų gaudavo tik iki paauglystès. Greičiausiai manyta, kad dovanos teikia džiaugsmą tol, kol vaikai maži ir dar bent kiek tiki Kaledų Senelio buvimu. Be to, ji augo sovietmečiu ir nelabai buvo „iš ko ir ką nupirkti“.

Nors kalédinès dovanos Lietuvoje pradejo plisti tik XX a. pradžioje, tačiau šiandien jos yra įsigalejusio šventinio ritualo neatsiejama dalis. Tai, kad dovanojimas yra abipusis veiksmas / įsipareigojimas, pagrindžia ir pateikejjų nuostatos kalėdinio dovanojimo atveju.

\section{DOVANA IR STRESAS}

Kalėdinės dovanos džiaugsmo ir teigiamų emocijų šaltiniu tampa ją gavusiajam ir ją dovanojančiajam. Tyrimas atskleidè, kad ruošiant dovaną visada galvojama apie asmení, kuriam dovana skirta, ir siekiama patenkinti jo lūkesčius.

Kalėdinių dovanų teikimas apima platų ratą - dovanomis keičiamasi ne tik šeimoje, bet su giminèmis, o kartais ir draugais. Dovanų rinkimui, pirkimui ar gaminimui ruošiamasi

(9) Šiame straipsnyje apsiribosiu tik šeima ir plačiau šio reiškinio neanalizuosiu. 
labai atsakingai. Paklaustos, ar dovanas įsigyja iš anksto, ar perka spontaniškai, visos pateikejjos ịvardijo pirmąji variantą. Joms reikia paruošti gana daug - neretai 10-30 dovanų. Siekis paruošti tiek dovanų daugeliui gali sukelti nemenką stresą, kuris, remiantis J. Helslooto pateiktu apibrèžimu, yra mentalinè būsena, atsirandanti suvokus neatitikimą tarp individams keliamų reikalavimų ir gebejimų susitvarkyti su jais. Laikomasi nuostatos, kad stresas nèra tik individualios psichologijos reikalas, bet yra socialinė kultūrinè kategorija, metafora, vartojama socialiniame gyvenime ịkūnytoms patirtims apibūdinti, todèl taip pat yra etnologinio tyrimo objektas $[6,155]$. Kita vertus, dovanų teikimas tampa svarbiu šeimos šventės ritualu bei esminiu šios šventės akcentu, dèl kurio sèkmès nuolat baiminamasi. Šventinị stresą sustiprina visuomeninis spaudimas, nes šiuo laikotarpiu dažnas rūpinasi dovanomis ne tik savo šeimos nariams, bet ir tiems, iš kurių patys yra gavę dovanų, taip pat norėdami pamaloninti draugą, pažįstamą ar viršininką.

Remdamasis olandų patirtimi J. Helslootas teigia, kad daugiau nei pusè respondentų nurode patiriantys stresą. Kartais tai susiję su fiziniais požymiais, bet dažniau su veiksnių - laiko stoka, pareigos jausmas, stengimasis laikytis aukštų reikalavimų ir kartu baimé patirti nesèkmę ar nusivylimą - deriniu [6, 156]. Aiškinantis, kaip vilnietès vertina šventinių dovanų ruošimo / pirkimo reiškini, tyrimas atskleidè, kad tik reta pateikèja jo nemėgsta. O pasiteiravus, ar laikas, praleistas ruošiant / perkant dovanas, joms buvo malonus, nelabai malonus ar sukèlè stresą, sulaukta daugiau atsakymų, kad buvo malonus. Kad dovanų ruošimas kelia stresą, kategoriškai atsakė mažuma moterų. Pavyzdžiui, dvi pateikejos ši procesą tiesiogiai siejo su patiriamu stresu, tačiau tik esant tam tikroms aplinkybèms: viena - kai tenka pirkti suaugusiesiems (nes pirkti dovanas vaikams jai malonu), antra - kai trūksta laiko. Kalbèdamos apie konkrečias patirtis pateikejos nurodè ir daugiau su stresu siejamų (tiesiogiai neįvardytų) veiksnių: patirtas fizinis nuovargis, idejjų stoka ar nepakankami finansiniai ištekliai.

\section{NAMIE PAGAMINTA DOVANA}

Antony ir Peteris Mialai, Viktorijos laikų Kalèdas palyginę su dabartinėmis, pažymèjo, kad ši šventė Anglijoje abiem laikotarpiais buvo saldumynų ir žaislų diena. Jų gaudavo ir gauna gausybę, bet Viktorijos laikų Kalėdų dovanos dažnai buvo pagamintos namie, o rankomis pagaminta kukliausia dovana buvo vertinama labiau negu gausybẻ brangakmenių [16, 2333]. XIX a. moterų rankų darbo dovanos gyvavo ir Vokietijoje [34, 148]. XX a. pradžioje tokios dovanos buvo dovanojamos ir Lietuvos kaime, pavyzdžiui, sesuo broliams dovanojo pirštines, žmona vyrui - šaliką $[8,215]$. Panašiai būta ir su vaikų dovanomis. Lietuvos kaime namų darbo žaislai, pasak Nijolès Pliuraitės-Andrejavienès, vyravo net iki XX a. vidurio. Namų darbo žaislus valstiečiai dovanojo ir per Kalẻdas, nors pasitaikydavo ir pirktinių žaislų, ypač amatininkų šeimose [21, 24-39].

Kasmet susiduriant su dovanų parinkimo problemomis nuolat ieškoma būdų, kaip sumažinti ar visai išvengti prieššventinès ịtampos. Vienas iš būdų, pasirenkamų kovojant su prieššventinio laikotarpio stresu, - rankų darbo dovanos. Be to, paaiškejo, kad taip dalis pateikejjų tęsė tėvų tradiciją gaminti dovanas pačioms, tikintis pratęsti perimtas tradicijas ir tam tikra prasme sakralizuoti dovaną.

1948 m. gimusi pateikejja nuo pat mažens savo vaikus skatino pačius daryti dovanas: dovanodavo vaikams rankdarbių knygutes, pati mokè. Moteris pasakojo, kad šis procesas vaikams labai patikdavo, nes ruošiant dovaną buvo galvojama apie konkretų žmogų ir tai, kas ji galètų pradžiuginti. Todèl iki šiol šeimoje yra išlikusi tradicija, kad kaledinès 
dovanos turi būti ją gavusiam staigmena, o tokia dovana kaip, pvz., dulkių siurblys nebūtų suprasta. Noras dovanoti savos gamybos dovanas būdingas ir jaunesnèms kartoms. 1977 m. gimusios vilnietės nuomone, dovanoti masinès gamybos daiktus yra „tuštybè ir laiko praradimas, o padarytas savom rankom - tai originalu“. Idejją padaryti pačioms pateikejjos sieja tiek su originalumu (mėginant nustebinti gavėją), tiek su būdu išvengti itampos perkant dovaną. Taip šią problemą prieš 2012 metų Kalèdas išsprende 1979 m. gimusi pateikèja: vyrui, vaikams, tėvams, uošviams, savo ir vyro seserims, geriausioms draugèms pati nuvèlè šlepetes.

Kita 1979 m. gimusi pateikejja pažymejjo, kad svarbu ne tik dovana, bet ir jos originali pakuoté, todèl daug laiko ir išmonès skiria dovanos ịpakavimui. Šis procesas pateikejjai yra labai malonus, nes taip ị dovaną įdedama (net jeigu ji ir pirktinè) dalelè širdies. Prie kiekvienos dovanos ji dar paprastai prideda pačios iškeptų ir gražiai supakuotų sausainių ar pyragą. Šiemet pati gavo muilą, pagamintą jai dovanojusio asmens. Ši idejja jai labai patiko, todèl mano, kad ateityje ne tik dovanos savo kepinius (kuriuos dabar ịvardija kaip priedą prie dovanos), bet ir pati gamins rankų darbo dovanas. Apie rankų darbo dovanas mąsto ir kitos moterys. 1979 m. gimusios vilnietès teigimu, jai dovanų ruošimas nèra jokia problema, tačiau pripažìsta, kad auginant du mažus vaikus nuolat trūksta laiko dovanų pirkimui, o trumpéjant laikui didẻja stresas, todèl dovanų gaminimas padètų racionaliau paskirstyti laiką ir suteiktų malonumą. Kol kas dèl neigyvendintų svajonių jaučia tam tikrą nepasitenkinimą, kurị pati îvardija „slogučiu“. 1977 m. gimusi pateikeja taip pat augina du mažamečius vaikus. Moters teigimu, nors jai pačiai patinka gaminti dovanas, tačiau susitaiko su situacija, kai serga vaikai ar nespeja. Kadangi dovanos daugiausia skiriamos vaikams, dovanoja smulkmenas, saldumynus, nors, kita vertus, yra gana kategoriškai nusistačiusi nedovanoti „bet ko“. Negalèdama ịvykdyti išsikeltų reikalavimų nereta pateikejja sugeba surasti išeitį, kaip kompensuoti šį nusivylimą ir išvengti streso.

Dovanos gaminimas yra ne tik būdas sumažinti ar visai išvengti įtampos, patiriamos ieškant dovanos parduotuvejje, bet ir priemonè realizuoti asmeninius kūrybinius poreikius, taip pat siekis maksimaliai sumažinti „netinkamos dovanos“ - „nepavykusio ritualo" riziką.

\section{PERKAMA DOVANA}

Gaminant ar renkant dovaną parduotuveje siekiama to paties tikslo - išrinkti tinkamą dovaną. I klausimą, ar patenkintos 2012 metų Kaledoms paruoštomis dovanomis ir ar jomis buvo patenkinti jas gavusieji, visos atsakè teigiamai. Tačiau stengdamosi maksimaliai iggvendinti išsikeltus reikalavimus dažniau stresą / ịtampą patyrẻ pirkusios dovanas.

Nors teoriškai su dovanos idejuc problema gali susidurti tiek jas gaminančios, tiek ir perkančios, tačiau praktiškai dažniau ją patyrė moterys, pasiryžusios pirkti. Pasak $1976 \mathrm{~m}$. gimusios pateikejjos, jai lengva dovanas rinkti tada, kai konkrečiai žino, ką ir kam pirks, tačiau „kai renkant dovanas nèra idejos - tai yra stresas“. Būdą, kaip susidoroti su šia problema, pateikè 1979 m. gimusi pateikejja. Moteris sakè: „Stengiuosi dovanoti tai, ko konkretus žmogus nori, nes paprastai šeimos rate pasipasakojam, apie ką svajojam, ko kam reikia. Nors kasmet būna nauji norai, tačiau turèdama iš anksto idèją, ją gana lengvai igyvendinu."

Tam, kad užtektų pakankamai laiko ne tik idejjoms subrandinti, bet ir joms igyvendinti, dažnai ilginamas dovanoms pirkti skirtas laikas, t. y. pratęsiamas priešventinio pasiruošimo 
laikotarpis. 1948 m. gimusi moteris pradeda apie dovanas galvoti ir jas pirkti prieš du mènesius, kad „paskutinę dieną prieš šventes nereikètų stovėti eilejje ir stresuoti, kad kažką nupirktum“. Sąmoningai pasirinktas didesnis laiko tarpas pateikẻjai leidžia ramiai ieškoti dovanų: kartais pamato daiktą ir nuperka, kartais pasilieka laiko pagalvoti.

Nemažai laiko reikia tada, kai planuojama pirkti daug dovanų - ne tik patiems artimiausiems šeimos nariams, bet ir giminèms ar draugams. 1976 m. gimusi pateikèja teigè, kad jos yra labai didelè giminè ir ruošia jai simbolines dovanas, tačiau jų reikia apie 20. 1963 m. gimusi moteris pasakojo, kad kasmet perka apie 15 dovanų. Jų šeimoje jau nusistovèjo tradicija, kad Kūčių vakarienèje dalyvauja vyro tèvai (pateikèjos - jau mirę), o Kalèdų pirmą dieną atvažiuoja jos ir vyro broliai su šeimomis. Nors Kalèdų rytą apsikeičiama dovanomis, suvažiavus giminėms - vèl vyksta ta pati dovanų keitimosi ceremonija. Pateikèja dovanų pradeda ieškoti jau nuo spalio mènesio. Moters patirtis rodo, kad beveik kasmet tenka nors vieną dovaną pirkti prieš pat šventes, pavyzdžiui, tuo atveju, jeigu pamanè, kad išrinko netinkamą dovaną, ar netyčia sužinojo, kad išrinkta dovana konkrečiam žmogui yra ne ta, kurios jis norètų. Tada tenka patirti nerimo, bet ne streso. Pasak pateikejjos, „šiais laikais (nes ji dar gerai atsimena sovietmečio situaciją) vis tiek galima greitai surasti norimą daiktą. "Vadinasi, sukaupta patirtis ir pozityvus nusiteikimas taip pat gali padèti išvengti streso. Tačiau ne visos išvengia šios būsenos. $1976 \mathrm{~m}$. gimusi pateikèja teigè, kad nors dovanas pradèjo pirkti gruodị ir iš anksto „nužiūrèti“, ką norètų pirkti, bet ši problema jai išliko.

Kiti įvardyti veiksniai, lemiantys gerą apsipirkimą, yra „laikas ir finansai“. Labai svarbu ivvertinti, kiek ir kada šeima gali skirti lèšų dovanoms ịsigyti. Skirdama daugiau laiko dovanų rinkimui / pirkimui 1976 m. gimusi pateikejja mano, kad taip naudingiau išleidžia pinigus, perka tik gerai apgalvojusi, o seniau pasitaikè, kad pirkdavo ir „bet ką, nes prieš pat šventes nebelikdavo laiko“. Tokiu atveju graužatis, kad galèjo nupirkti pigiau ir tinkamesnę dovaną, išlieka ilgam.

Taip pat būtina ịvertinti ne tik laiko, finansinius, bet ir fizinius išteklius, kurie gali tapti prieššventinès įtampos priežastimi. 1977 m. gimusios pateikèjos nuomone, stresas užklumpa tada, kai suplanuoji daugiau, nei esi fiziškai pajègus padaryti. 1979 m. gimusiai pateikejjai ši jauduli mažina jos nuostata: nors ir stengiasi, kad visiems dovanos patiktų, tačiau ramiai susitaiko su tuo, jeigu išeina ne taip, kaip nori, ir viliasi, kad galès „pasitaisyti“ kitais metais.

Tyrimas atskleidè, kad pasirenkant dovanos ruošimo būdą, siekiama emocinio komforto, t. y. ne tik sau keliami reikalavimai, bet ir stengiamasi su jais susitvarkyti, todèl pasirenkamas vis ilgesnis laikas idejoms brandinti ir dovanoms pirkti. Pasikliaujama daugiamete patirtimi, mažinamas fizinis ir emocinis krūvis. Vis dèlto dovanų pirkimas dažniau sukelia ịtampą nei jų gaminimas, todèl kartais bandoma pasinaudoti ne vienu iš minètų būdų, bet susikurti visą kompleksą taisyklių ar net tam tikrą gyvenimo būdą, padedantị „susikurti“ malonų prieššventinị laikotarpị.

\section{PRIEŠŠVENTINIS LAIKOTARPIS - STRESO VALDYMAS}

Kalėdos yra viena svarbiausių krikščioniškų švenčių, jungiančių advento rimtị ir tarpušvenčio linksmybes. J. Kudirka pažymèjo, kad tradicinėje kaimo kultūroje labai daug dèmesio buvo skiriama pasiruošimui šiai šventei. Pasak autoriaus, tai adventinis susikaupimo laikas, dvasinis apsivalymas, Kūčių darbai ir namų ruoša, prieššventinė pirtis, kambario puošimas, eglutès rèdymas, stalo paruošimas $[8,215]$. 
Prieškalèdiniu laikotarpiu patirtos teigiamos emocijos yra ilgai lauktų švenčių geros nuotaikos pagrindas ir šių dienų kultūroje. Tyrimo metu buvo aiškintasi, kokias emocijas sukelia prieššventinis laikotarpis ne tik dèl dovanų, bet ir dèl maisto pirkimo, gaminimo bei šventinio stalo, namų puošimo. Pateikejjų klausta, ar šis laikas jiems buvo malonus ar sukèlè, pavyzdžiui, stresą. Tyrimas rodo, kad „susikurti“ ramų laikotarpi gali padèti tam tikros tvarkos nustatymas ar naujų ritualų atsiradimas. Paprastai sukurtos tvarkos laikomasi ne vienus metus, ypač jeigu ji pasiteisina. Priešingu atveju, siekiant konkretaus rezultato, procesą stengiamasi tobulinti: mažinamos laiko ar finansinès sąnaudos, siekiama didesnio emocinio komforto, vengiama streso. Tikslo siekiama drastiškai, dažnai atsisakant senųjų šeimos tradicijų ar ritualų, ir tai dažniausiai lemia pateikèjų tėvų namuose vaikystėje ar jaunysteje gauta neigiama patirtis.

Pastebimas noras keisti tèvų šeimoje gyvavusias tradicijas. 1979 m. gimusios pateikèjos nuomone, ir jos mamai, ir anytai pasiruošimas (kurị nuolat stebejjo švęsdama tai pas vienus, tai pas kitus) šventėms yra stresas, nes eikvojama per daug energijos, pavyzdžiui, siekiant maisto gausos ar tobulai sutvarkyti namų aplinką. Todèl, anot moters, „pati iš pasiruošimo stengiuosi „nedaryti“ streso ir šventinès vakarienès sulaukti nepavargusi nuo darbų, noriu kasmet susikurti šventę sau ir artimiesiems.“ Nors 1982 m. gimusi pateikèja sakè, kad laikytis tam tikros tvarkos yra gerai, keisti tèvų šeimoje gyvavusias tradicijas ir sukurti „kažką savo“ greičiausiai paskatino jos vyro šeimos, kuris užaugo Prancūzijoje, patirtis. Jo tèvai lietuviai, gyvendami Prancūzijoje, igijo naujos patirties, kuri jai tapo priimtinesnè nei gauta iš tèvų. Moteris pasakojo, kad „jos šeimoje visą prieššventinị pasiruošimą atlikdavo viena mama, todèl labai pavargdavo, o šventè tapdavo tarsi privaloma ir tas nepatikdavo. Dovanos neteikdavo džiaugsmo, nes nebuvo sukuriama šventinè atmosfera. " Savo šeimoje išsikèlę planavimo idejją netrukus patyrè, kad tinkamas laiko planavimas ir darbų pasidalijimas tarp šeimos narių prisideda prie šventinés nuotaikos sukūrimo. Jos nuomone, pavykusios šventès esmè yra „ne dovanos ar maisto kiekis, o sukurta šventinè atmosfera“. Tai, kad pagal išgales vis dažiau vyras ir vaikai prisideda prie šventès rengimo, paminèjo ne viena XX a. 8-ąji dešimtmeti gimusi pateikejja.

1979 m. gimusi pateikejja, kuri prieššventiniu laikotarpiu seniau neišvengdavo streso, taip pat susikūrè tvarką / sistemą, kaip greičiau ir ekonomiškiau pasiruošti šventėms. Pirma, ji pailgino dovanų pirkimo laiką - dabar pradeda pirkti nuo Vèlinių; antra, visus metus fiksuoja ir užsirašo bet kuriomis aplinkybemis išgirdusi apie savo artimųjų ar draugų pageidaujamas dovanas, ji pasižymi ir kur galètų tą daiktą ịsigyti. Pateikèja kasmet paruošia apie 30 dovanų ir tvirtina, kad dabar dovanų pirkimas jai tapo maloniu žaidimu. Tos pačios tvarkos ji laikosi jau kurị laiką - gal tik kasmet vis prailgina dovanoms ruošti skirtą laiką. Iš dovanas gavusiųjų komentarų ji patyrè, kad jos sumanymas visiškai pasiteisimo ir dovanomis lieka patenkintos abi pusès (perkančioji ir gaunančioji).

Gana ilgas oficialus prieššventinis laikotarpis, kai jau nuo gruodžio mènesio pradžios puošiamos miesto gatvès, kalėdines puošmenas ir dovanas siūlo prekybininkai, vyksta vakarèliai darbo kolektyvuose ir kita, priimtinas ne visoms pateikejoms. 1979 m. gimusiai vilnietei tai ne tik nepatinka, bet ir sukelia stresą, nes, pasak moters, „šventės pastaruoju metu igyja vis labiau komercinị pobūdị. Prasideda jau nuo gruodžio pradžios. Geriau iki šventès būtų ramybė ir tada šventès būtų išlauktos."

$2011 \mathrm{~m}$. analizuodama tradicijos sampratas šiuolaikinejje Lietuvoje pastebejjau, kad „mažoji“, šeimoje puoselèjama tradicija ar paprotys gali būti suvokta kaip archajiškesnè, 
kita vertus, ir ne tokia stabili kaip platesniame sociume puoselëjama „didžioji“ (tautos) tradicija [19, 214-215].

Suprantama, kad kiekvienas iš mūsų pasirenkame, kaip ruošti, švęsti šventes ar kurti savo šeimos šventinius ritualus. Tyrimas rodo, kad neretai sena tradicija atmetama ir pasirenkamas individualus būdas, padedantis išvengti streso. Šis reiškinys paplitęs tarp jaunesnès kartos vilniečių.

\section{IŠVADOS}

Atliktas tyrimas atskleide ịsigalejjusią kalèdinių dovanų teikimo tradiciją vilniečių šeimose ir tai, kad prieššventiniu laikotarpiu išgyvenama emocinė ịtampa, o dovanų teikimas suvokiamas kaip būtinas šventès ritualas. Nuogąstavimai, kad jis gali nepavykti, sukèlè įtampą daugeliui apklaustųjų, tačiau tik nedidele dalis jų tai įvardijo kaip „stresą“.

Pateikèjų komentaruose matome siekị išvengti streso ar jị sumažinti pasirenkant individualų būdą: pagaminti rankų darbo dovanas, pratęsti dovanų pirkimo laiką, ị namų ruošą įtraukti vyrą ir vaikus, susikurti savo šeimos ar kitaip koreguoti tėvų namuose igytą pasiruošimo šventèms patirtị. Jaunesnès kartos apklaustieji realiau vertina prieššventinę situaciją, sugeba ịveikti iškilusias problemas ir sukurti šventę sau bei artimiesiems.

Taigi ị klausimą, ar Lietuvoje per šventes taip pat patiriamas ritualinis „stresas“, galima atsakyti - „taip“. Remiantis vilniečių apklausos duomenimis (nors kiekybiniu požiūriu tyrimas apima tik nedidelę dalị vilniečių), prieššventiniu laikotarpiu atsirandančią ịtampą / stresą galime sieti su energijos (fizinių jẻgų), idejjų ir išmonès (keliamų reikalavimų dovanai), laiko bei finansinių išteklių stygiaus sukeltu diskomfortu.

Gauta 20131113

Priimta 20131210

\section{Literatūra}

[1] ALIŠAUSKIENÉ, Milda; SAMUILOVA, Ina. Modernizacija ir religija sovietinèje ir posovietinèje Lietuvoje. Kultūra ir visuomenè, 2011, Nr. 2(3), p. 67-81.

[2] BALYS, Jonas. Lietuvių kalendorinès šventès. Tautosakos medžiaga ir aiškinimas. Vilnius: Mintis, 1993.210 p.

[3] ERIKSEN, Tomas Hylland. Akimirkos tironija. Greitasis ir lètasis laikas informacijos amžiuje. Vilnius: Tyto alba, 2004.199 p.

[4] GIEREK, Bożena. Celebration of Christmas in Contemporary Poland. The Ritual Year 6. The Inner and the Outer. Tartu: Estonian Literary Museum, Department of Folkloristics, 2011, p. 219248.

[5] GUTAUTAS, Stasys. Lietuviu kalendorinès šventès. Vilnius: Vyturys, 1991. 88 p.

[6] HELSLOOT, John. Stress and Ritual. December Family Traditions in the Netherlands Today. Lietuvos etnologija. Socialines antropologijos ir etnologijos studijos, 2011, No. 11(20), p. 143-157.

[7] KLIMKA, Libertas. Pilietiškumas ir tautiškumas: laiko dimensijos ir aktualijos. Iš: Tautiškumas ir pilietiškumas. Atskirtis ar dermè? Vilnius: Vilniaus pedagoginio universiteto 1-kla, 2007, p. 127141.

[8] KUDIRKA, Juozas. Lietuviškos Kūčios ir Kalèdos. Vilnius: Vaga, 1993. 316 p.

[9] KUDIRKA, Juozas. Lietuviškos Kūčios. Istorine lyginamoji apžvalga. Vilnius: Lietuvių liaudies kultūros centras, 1994. $63 \mathrm{p}$.

[10] KUZNECOVIENĖ, Jolanta. Šventes švenčiantis lietuvis: bendruomeniškumo diapazonas. Iš: Lietuviškojo identiteto trajektorijos. Sud. V. Čiubrinkas, J. Kuznecovienè. Kaunas: Vytauto Didžiojo universitetas, 2008, p. 75-88. 
[11] MARDOSA, Jonas. Socialistinio Lietuvos kaimo gyventojų dvasinè kultūra. Vilnius: Mokslas, 1988. $94 \mathrm{p}$.

[12] MARDOSA, Jonas. Švente mieste: Keletas kūrimo ir funkcionavimo problemų. Iš: Šventès šiuolaikiniame mieste. Festivals in the Modern City. Sud. J. Mardosa. Vilnius: Edukologija, 2013, p. 52-60.

[13] MARCINKEVIČIENĖ, Nijolè. Apie Advento-Kalèdų laiką ir papročius. Iš: Atvažiuoja Kalédos. Advento-Kaleddu papročiai ir tautosaka. Vilnius: Lietuvos liaudies kultūros centras, 2000, p. 9-25.

[14] MAUS, Marcel. The Gift. The Form and Reason for Exchange in Archaic Societies. London, New York: Routledge, 2002. 199 p.

[15] MERKIENĖ, Irena Regina. Punsko ir Seinų krašto lietuvių Kūčios etnokultūriniame kontekste. Iš: Punsko ir Seinu krašto lietuviai. Etninio ir kultūrinio tapatumo bruožai. Sud. P. Kalnius. Punskas: Aušra, 2006, p. 169-190.

[16] MIAL, Antony \& Peter. The Victorian Chrismas Book. London: Treasure Press, 1990. 192 p.

[17] MORKŪNAS, Vitalis. Nuo tamsos ligi tamsos. Vilnius: Mokslas, 1977. 202 p.

[18] ŠAKNYS, Žilvytis Bernardas. Kalendoriniai ir darbo papročiai Lietuvoje XIX a. pabaigoje XX a. pirmoje pusèje. Jaunimo vakareliai. Vilnius: Diemedis, 2001. 156 p.

[19] PAUKŠTYTĖ-ŠAKNIENĖ, Rasa. Tradicijos sampratos šiuolaikinèje Lietuvoje. Lituanistica, 2012, Nr. 2(88), p. 206-217.

[20] SALAMONE, A. Frank. Christmas. Iš: Encyclopedia of Religious Rites, Rituals, and Festivals. Ed. F. A. Alamone. New York, London: Routledge. 2004, p. 85-89.

[21] PLIUTAITĖ-ANDREJEVIENĖ, Nijolè. Lietuvos vaikų žaislai. Vilnius: Versus aureus. 336 p.

[22] SENVAITYTĖ, Dalia. Kalendorinių švenčių diskursas sovietinëje Lietuvos periodikoje. I dalis: 1945-1964 metai. Lituanistica, 2013, Nr. 2(92), p. 101-121.

[23] SIMPSON Jacqueline, Roud Steve. A Dictionary of English Folklore. Oxford: Oxford University Press, 2000. 412 p.

[24] Theorizing Rituals. Classical Topic. Theoretical Approaches, Analytical Concepts. Eds. J. Kreinath, J. Snoek, M. Stausberg. Leiden, Boston: Brill, 2008, p. 395-411.

[25] VAICEKAUSKAS, Arūnas. Kalèdų senelio kilmè. Liaudies kultūra, 2010, Nr. 6, p. 32-38.

[26] VAICEKAUSKAS, Arūnas. Lietuviu žiemos šventès. Bendruomenès kalendorinio ciklo apeigos XIX a. pab. - XX a.pr. Kaunas: VDU 1-kla, 2005. 192 p.

[27] VAN GENNEP, Arnold. The Rites of Passage. London: Routledge and Kegan Paul. 1960. 198 p.

[28] Viduramžiu žodynas. Sud. P. Dinzelbacher. Vilnius: Aidai, 2004. 607 p.

[29] VYŠNIAUSKAITĖ, Angelè. Naujų tarybinių papročių formavimasis. Iš: Lietuviu etnografijos bruožai. Vilnius: Valstybinè politinès ir mokslinès literatūros 1-kla, 1964. p. 551-567.

[30] VYŠNIAUSKAITĖ, Angelè. Mūsu metai ir šventès. Kaunas: Šviesa, 1993. 152 p.

[31] WELCH, Wendy. Festival. Encyclopedia of Women's Folklore and Folklife, 2009, Vol. 1, p. 175181.

[32] ZNAMIEROWSKA-PRÜFFEROVA, Maria. Vilnius, miestas arčiausia širdies. Vilnius: Alma litera, 2009. $312 \mathrm{p}$.

[33] РИКМАН, Эммануил Абрамович. Место даров и жертв в календарной обрядности. Календарные обряды и обычаи в странах зарубежной Европы. Отв. ред. С. А. Токарев. Москва: Наука, 1983, с. 173-185.

[34] ФИЛИМОНОВА, Т. Д. Немцы. Календарные обряды и обычаи в странах зарубежной Европы. Москва: Наука, 1973, с. 139-161. 


\section{RASA PAUKŠTYTÉ-ŠAKNIENĖ \\ Preparation for Christmas Festivals in the families of Vilnius citizens: Is it a stress or a pleasure?}

Summary

Several years ago John Helsloot published an article "Stress and Ritual. December Family Traditions in the Netherlands of Today". On the basis of the theoretical approaches to ritual performance of the supporters Edward Schieffelin, Clifford Geertz and Ronald Grimes, the ethnologist is analyzing preparing for and performing the rituals of the month of December (St. Nicholas, Christmas) in the Netherlands as a risky, likely to fail and causing stress.

My work analyses the preparation for Christmas period festivals by Vilnius citizens with reference to the inducement of a Dutch scientist to examine the existence of a ritual stress in other countries. The article is based on the material of the examination of the ethnographic fieldwork in 2013 (collected by the author herself via her own questionnaire). The research has revealed that recently a tradition of giving presents to each other during Christmas has been deeply rooted in the families of Vilnius citizens despite an inducement of the tradition to give presents on New Year's Day so popular in the Soviet period of time. Moreover, it has also been proved that it is emotional tension which is experienced in the pre-festival period, whereas the action of giving presents is perceived as an essential ritual of Christmas. A fear of failure was expressed by the majority of the respondents, however, only a small part of them mentioned stress. The commentaries of the people questioned prove an ambition to escape stress or, at least, relieve from it individually, for instance, by handmade presents, prolonging the period of time intended for buying presents, also by involving a husband and children into a traditionally female sphere of household chores or creating personal traditions of the preparation for festivals or combining them with the experience gained from parents. The research has shown that the respondents of a younger generation distinguish in a practical perception of a pre-festival situation, i. e. an ability to cope with the lack of time, finance and ideas as well as a capability to create a festival for himself (herself) and close people.

Key words: stress, Vilnius, Christmas presents, Christmas Eve, family 